удк:

ПОЛИТИЧКА РЕВИЈА

$327.84+355.40$

POLITICAL REVIEW

Прегледни

Година (XXIV) XI, vol=33

рад

Бр. 3 / 2012.

стр. 299-325.

Mladen Bajagic*

Academy of Criminalistic and Police Studies

\title{
WHY THEORY OF INTELLIGENCE ACTIVITIES
}

\begin{abstract}
Summary
In this work an effort has been made to obtain a comprehensive review and analyze different conceptual designations of the intelligence activities resulting from both individual and theoretical research efforts as well as many institutional definitions regarding this phenomenon. Furthermore, there are special research approaches in comprehension of the intelligence activities phenomenon and its conceptual designation, systematically presented in this study. At the same time importance and significant role of the paper's main issue (intelligence activities) was born in mind, related to preserving and promoting national security as a part of foreign policy creating and realization process. Finally, this subject has to do with defining the national interests. Based on these theoretical assumptions, taking into account the general concept of scientific theory and theory in the social sciences, this piece of work realizes the phenomenon of intelligence activities in a historical context and furthermore it attempts to outline and justify building and conceptual elements which are foundation of the very theory of intelligence activities as a specific and special scientific approach to understanding the concept of intelligence within the framework of social and political, that is security phenomenon in the broadest sense.
\end{abstract}

Associate Professor Mladen Bajagić, PhD, E-mail: mladenba@yahoo.com. This paper is the result of the realisation of the Scientific Research Project entitled „The Development of Institutional Capacities, Standards and Procedures for Combating Organized Crime and Terrorism in the International Integration Conditions". The Project is financed by the Ministry of Education and Science of the Republic of Serbia (No 179045), and carried out by the Academy of Criminalistics and Police Studies in Belgrade (2011-2014). The leader of the Project is Associate Professor Saša Mijalković, PhD. 
Key Words: intelligence, Theory of Intelligence, foreign policy, security, national security, counterintelligence, covert actions

\section{DIFFERENT UNDERSTANDINGS OF THE CONCEPT OF INTELLIGENCE ACTIVITIES}

Scientific and theoretical analysis of the concept of intelligence depends on the purpose of using the term intelligence, or on what it specifically labels. At a basic and benign level analysis, intelligence can be defined simply as processed information. Or it can be more specific when it is described as being knowledge and analysis designed to assist action (Quiggin, 2007). Intelligence activity is always linked to the fate or survival of a state and the preservation of common interests and values of a community. It largely determines the way we anticipate the reality around us as well us changes that occur daily and can have a negative impact on us. Confirmation of these positions is found in the number of the meanings of the term intelligence:

1. To perceive things in the germ is intelligence... The heart of intelligence is getting at and faithfully representing the truth.... All the knowledge which we have of the enemy and his country; therefore, in fact, the foundation of all our ideas and actions (Lathrop, 2004);

2. Intelligence is an instrument of conflict. It consists of words, numbers, images, suggestions, appraisals, incitements. It consists also of truths that enlighten or mislead, or of outright falsehoods. Because it is immaterial, intelligence cannot wound. But its use has led to the killing or saving of millions (Codevilla, 1992);

3. The term foreign intelligence means information relating to the capabilities, intentions, or activities of foreign governments or elements thereof, foreign organizations, or foreign persons (Warner, 2002);

4. Intelligence is the knowledge - and, ideally, foreknowledge sought by nations in response to external threats and to protect their vital interests, especially the well-being of their own people (Jentelson \& Paterson, 1997);

5. Intelligence simply stands for collecting necessary information for those who request them. In foreign policy and national 
security, intelligence has duty to direct foreign policy decision makers and help them to carry out wisely their aims (DeConde, 2002);

6. Intelligence designates secret actions, extension of the war by the means of secret operations (secret interfering of one power in the affairs of the other), which have their utmost goal to diminish the power of the other side and meddle in their affairs (Bruneau, 2008);

7. Intelligence has two main purposes: Firstly, to inform policy, and secondly, to support military, police and some other operations which have protection of national security as their utmost goal (Bruneau, 2008).

8. Intelligence denotes significant political information, subjected to the processing and analysis, and assigned to key decision makers within government (Turner, 1991);

9. Intelligence is a unique activity that includes collecting and analyzing information and their conversion into intelligence knowledge, and some other activities, too (counter-intelligence and covert actions). Intelligence gathering has the following forms: open source collection; clandestine collection; human source collection; and technical collection (Richelson, 1999);

10. Intelligence indicates collection of political, economic or military data on potential enemies, and one of the most sophisticated branches of the executive (Scruton, 2007);

11. Intelligence refers to a special kind of knowledge necessary to accomplish a mission - the kind of strategic knowledge that reveals critical threats and opportunities that may jeopardize or assure mission accomplishment. Intelligence often reveals hidden secrets or conveys a deep understanding that is covered by complexity, deliberate denial, or outright deception (Waltz, 2009);

12. Intelligence has several meanings, but two especially significant: 1 / intelligence is an activity and a process, and therefore it has usually been spoken of "conducting intelligence work"; $2 /$ intelligence is the final product of its kind as a final result of the intelligence work (McDowell \& Goodman, 2009).

According to the "Concise Oxford English Dictionary", intelligence is defined as a "synthesis of that what is known and integrated with new information, and finally interpreted in its true meaning." A 
similar definition of intelligence is given by Edward Waltz, who defines it as: 1/ a special kind of knowledge that needs to be achieved, the strategic knowledge that reveals the threats and points out different abilities and ways of realizing the planned mission (goals); $2 /$ activity that is to reveal the secrets of others and to provide a thorough understanding of others' conscious and hidden intentions, plans and deceptions (Waltz, 2009). In The Encyclopedia Britannica the same term means the process of supplying of political decision makers with knowledge concerning the present situation trends, capabilities and intentions of foreign countries and groups within them because information is the basic element of national power in a world that is characterized by a large number of sovereign states. Intelligence also includes the estimated/verified information, and as such is often the fundamental point of making major national decisions. The character of the concept of intelligence as a specific activity is illustrated in the Executive order of the President of the United States (Executive Order No. 12333) made in 1981, according to which the intelligence system is defined as a system responsible for providing the President and U.S. National Security Council / NSC with necessary information that is the starting point and basis for decision making regarding the management and development of foreign, defense and economic policy, as well as protection of the U.S. national interests from security threats coming from abroad. According to the official definition of the CIA, intelligence's primary task is to let American leaders know what is happening outside the U.S. in order to be prepared for what might happen in the future (Troy, 1991). According to the USA Patriot Act, foreign intelligence includes: " $\mathrm{a} / \mathrm{in}-$ formation, regardless of whether the proceeds from U.S. citizens or not, concerning the U.S. ability to protect against: (1) actual or potential attack or other grave acts made by the enemy or its representative, (2) sabotage or international terrorism encouraged or carried out by foreign power or its agents, (3) secret intelligence activities (espionage) or foreign agents networks; $\mathrm{b}$ / Information related to foreign powers or their territory of interest for: (a) national security and defense of U.S., or (b) the implementation of U.S. foreign policy.

Sherman Kent enlarges the concept of intelligence including the strategic intelligence as additional point. He defines it as a foreign intelligence or high-level foreign positive intelligence, whose final product is knowledge, necessary for the welfare and security of the nation. This knowledge is vitally important for national survival, and must be ac- 
curate, timely and complete, in order to form the basis for the action on external level. Kent underlines three functional categories of strategic information intelligence: 1/ basic descriptive, 2/ current-reporting, and 3 / speculative-evaluate element or prognostic element of strategic intelligence activity. The latter is foundation for making estimates and forecasts about the future behavior of states at the international level and their intentions in relation to the opponent's national interests and national security. These findings include information about the strategic character of another state, its relations with other subjects of international relations, its power (sources and elements) and willingness to use its total resources (Stojanović, Đurić, Despotović, 2011) in the implementation of its strategic interests, as well as information about the weaknesses that may affect its strategic character, etc. (Kent, 1949).

As a result of strategic intelligence work, strategic intelligence findings provide for policy a general picture of the specific issues and long-term forecasts thus enabling the planning process for the future. Strategic findings mean analytical synthesis of information from different sources (espionage, diplomacy, SIGINT, ELINT, COMINT, IMINT, MASINT and OSINT), which all together are the basis for informing the holders of political power and for making key decisions in area of national security and strategic foreign policy achievements (Russell, 2010). Strategic intelligence assessment is the final all-source intelligence product of actionable knowledge provided to government to anticipate or reduce uncertainty in its pursuit or protection of international political, economic and security objectives (Quiggin, 2007).

In addition to collecting information intelligence, the second aspect of the concept of intelligence is the analysis or integration of raw intelligence into finished intelligence, which should be a simple statement of facts, ability estimations of the other nations' military forces, or the projection of the likely trends of political events in another country. Other activities included in the notion of intelligence are covert actions and counterintelligence. Counter-intelligence activity itself involves information gathering and neutralizing the activities of foreign intelligence services (espionage, investigation of deserters, analysis of hostile intelligence services' methods, and direct infiltration and disruption of activities of those services (Richelson, 1999; Bajagić, 2009).

Facts, or awareness and knowledge about the dangers and circumstances that lead the states in a conflict can be provided only by careful collection of information on major events, surroundings, and intentions 
around the world. As a complex concept, the term intelligence has four basic meanings: 1/ "information - a tangible product collected and interpreted to obtain clear images of political and military situation in the world", 2/ process - a series of reciprocal steps that make up the intelligence cycle; $3 /$ tasks: a/ collection and analysis as the basis of the intelligence cycle, $\mathrm{b} /$ counter-intelligence tasks that prevent covert activities directed against the U.S. by foreign entities (usually hostile intelligence services), c/ covert actions, also called "special activities", which involve covert interference in the affairs of other states, and 4/ structures or organizations that perform the tasks described above. Intelligence in this sense means the current network of institutions involved in collecting, processing, interpretation and distribution of information. Furthermore, it includes institutions that plan and implement counter-intelligence activities and covert action (Johnson, 1996). Strategic intelligence as the basis of foreign policy is the core of successful management of foreign policy, the proper understanding of world events, thus clearing the path for decision-making before the foreign policy decision-makers (Johnson, 1991).

\section{THE INTELLIGENCE ACTIVITY CONCEPT}

The term intelligence is derived from the Latin word disclose, betray, reveal. Its prefix "inte" is derived from the prefix "inter" which in Latin means between or among. The second part of the word intelligence comes from the Latin words "leger" - which primarily means the collection of fruits or vegetables. Over time, these two entries - inter and legere in meaning of the above, were merged into one, which got the meaning of knowledge or skill needed to distinguish between good and bad fruit and vegetables. Gradually, the word intelligence had been created, indicating the skill and ability (willingness), needed to make wise choice of the most productive way of life. Born of the previous word, the modern notion of intelligence refers to knowledge and information necessary for important political decisions which have to be brought. On the other hand, it is important to note the distinction between the concept of intelligence in psychology, and its understanding referring to the foreign policy, national security, and security in general. In this regard, one can speak of similar meaning of the terms intelligence and "intelligence quotient" (IQ) and intelligence activities, because both essentially mean the ability to collect and process data about the envi- 
ronment (the world around us), as a prelude to obtaining knowledge, needed to make strategic decisions in life or in public affairs (Johnson, 2007). In Russian, the term used for intelligence is "razvedka" which is defined as a theory and practice of gathering information about the enemies who are important for security and defense, policy or economy. The meaning of this word also encircles the concept of organized activity of specialized institutions of government using in their work legal methods of data collection (collecting and analyzing data from public sources, listening to the radio stations from abroad, with the help and surveillance of the intelligence satellites), as well as the methods defined as an illegal action, included in the terms such as "espionage" or “information theft" (Savić \& Bajagić, 2003; Bajagić, 2010).

The concept of intelligence is a synthetic concept which designates the activity and the organization (intelligence service), further, the process of intelligence work (the intelligence cycle) and finally, the intelligence products or information intelligence, from raw to finished, which is the utmost result of the entire intelligence work realized through the intelligence cycle (Hoogenboom, 2006). Intelligence is understood as an inevitable part of the management of knowledge, since it involves the collection, analysis, synthesis and transfer of information, with respect to the following cognitive hierarchy (levels) of knowledge: data, information, and final knowledge. The data is the first and lowest level of knowledge whose main sources are individual perception, primitive messages, human communication/conversation, and contents of SMS messages, electronic records, and scientific observations. In the intelligence literature the term raw intelligence and evidence is used for data, as the most important data elements in the context of their cognitive meaning. Information is another level of knowledge which consists of organized sets of data, sorted, classified, indexed and linked into a single unit which has to be further analyzed. Knowledge and prediction (forecasting) is the highest cognitive level, the final product, which provides a high level of understanding of the nature of information and the ability to understand the past and the future of those subjects that information were related to. This knowledge has its own static and dynamic content (Ibid).

These three cognitive levels of knowledge are always distinct, because the information represents analytically processed data, classified into one whole, which is to be further subjected to the higher and more complex processes of analysis. Eventually, based on the accuracy of 
this information, it ensures the highest level of cognitive skills - intelligence knowledge (prediction). Information intelligence per se may be: 1/ general (gives a general idea of the problems and participants we are interested in - of individuals or groups within the game we perform), 2/ liquid or operational (monitoring the changes occurred under the circumstances), $3 /$ concrete (fill in the gaps identified or respond to certain questions), $4 /$ indirect (confirm or disprove certain assumptions with regard to the fact that it is related to them only indirectly) and 5/ estimative: clarifying the events and gives a forecast of their future development; these are optimally processed data (Ronin, 2009).

Intelligence understood as a specific information differs from information in the daily life in at least six points: 1/ the doom of ideologies, nations, economies and people can depend on the manner in which information intelligence is used, $2 /$ desired information is usually (though not always) information that other nations, groups and people do not want to have them published; 3 / desired information is about individuals, groups or nations that are often (but not always) the enemies or potential enemies to those who gather the information; 4/ gathering information is usually, though not always, made in a secret manner , 5/ individual, group or ethnic rights could be compromised by the intelligence operations, and 6/ intelligence activity in the broadest sense may include covert action involving the impact on foreign and domestic policies of other states without disclosing the actual source of this impact (Johnson, 2007). Professional intelligencers define the term intelligence in strategic and tactical sense. Strategic intelligence activity means "knowledge or foreknowledge about the world around us, which is an introduction to the presidential decisions and actions." In a tactical sense, intelligence refers to information about events and conditions in certain hot spots, including military situational awareness. However, the focus is on strategic intelligence, which ensures that national leaders understand the potential risks and successes at the national and international level. These findings may refer to threats on one's own territory (e.g. subversion carried out by domestic radical entities or infiltration of hostile intelligence structure or terrorist within the national territory), or other hazards or events from abroad.

Strategic intelligence in the context of global geographical dimension has other meanings. It most commonly refers to tangible intelligence information gathered, analyzed, evaluated and interpreted, in the hope that it will help understand more deeply subversive activity at 
home, or political, economic, social and military situation in the world (Johnson, 2007). As an example of strategic intelligence task a question can be taken that requires an answer on the whereabouts of Al Qaeda cells active in the world, which countries are secretly developing weapons of mass destruction, what are the political, security and economic conditions in certain war areas in the world, etc. A special importance is attributed to the Current intelligence, which is finished intelligence product that is delivered every day to the nation's top leadership. This is the synthesis of all relevant data obtained from minute-by-minute monitoring of certain phenomenon, event or issue that is the subject of intelligence research (Lathrop, 2004).

Given the similarities and differences in defining the concept of intelligence and the presented analysis of understanding the concept of intelligence in the expert literature, we can draw several important conclusions. First, in the theory of Intelligence, the notion intelligence most often designates the entire process of intelligence activities, but also the final intelligence product, or knowledge, or foreknowledge, which represents the unity of all the important information that intelligence received during the following activities: intelligence gathering, their assessment, analysis and integration, and, finally, their assignment to the political decision-makers responsible for the national security and foreign policy, in the form of systematized (final) intelligence studies. Second, finished intelligence form the basis and the starting point of foreign policy decision-makers for further consideration of possible courses of political action on external level, for defining more courses of action, choosing one direction, and the choice of means and procedures for the implementation of foreign policy objectives. Third, the expression of intelligence, in terms of activities, over time has been extended to counter-intelligence activities and covert action, thus placing the intelligence activity into direct contact with the process of realization of foreign policy goals, especially when it comes to covert actions.

So, intelligence within itself combines as well activities that do not represent the classical intelligence activity which is, above all, the covert action, or application of specific forms of force in international relations, "backstage games" of the covert interference in the internal affairs of other countries in order to achieve defined policy objectives (Bajagić, 2010). Finally, the notion of intelligence can be defined as an intelligence activity which makes the unity of interconnected stages (perception of intelligence problems, defining needs and requirements, 
collection, evaluation and analysis, interpretation, integration, production of final documents, the transfer and interpretation of intelligence findings). As knowledge, intelligence is the final intelligence product, synthesized intelligence knowledge, in different forms of intelligence documents transferred to end users - the real subjects of foreign policy decision-making process, as well as to others who directly participate in the implementation of the defined foreign policy objectives and the established directions of foreign policy actions. Therefore, when it comes to the concept of intelligence as a synthesis of specific activities and, of course, specific knowledge (cognition), we can say that in the sphere of foreign policy this concept implies the ability to notice cognitive ability, understanding and anticipating changes (new situations) in the international environment for each specific country and its national interests (Savić \& Bajagić, 2003; Bajagić, 2010).

\section{THE DEVELOPMENT OF THE INTELLIGENCE ACTIVITIES THEORY}

In the twentieth and early twenty-first century, the notion of intelligence found its place among the other concepts such as power and force, war, peace, conflict, cooperation, threats and challenges. At that time, Intelligence came into focus of the science of security, international relations and foreign policy, as well as some other disciplines within the corps of social sciences. It appeared as an unavoidable topic of discussion about power, national interests and national security (Bajagić, 2011). In discussions on so-called new economic strategies in the twenty-first century, the concept of intelligence is placed in direct correlation with knowledge: knowledge is the value, but intelligence is the power. So, the intelligence emerges as a phenomenon of paramount importance in the field of global economic relations under the term "business and competitive intelligence", beyond prevailing analysis of the role of intelligence activities in the field of national security and foreign policy. However, special importance is assigned to intelligence activity as a discussion issue on international and global security, given the new globalized challenges and security threats, as well as the fact that in the so-called "era of information revolution," the era of "thickening time and space", as a consequence of the general process of globalization, all the latest technical and technological achievements and communication achievements are universally applied to the field of intelligence activities. So, nowadays we may talk about a kind of intel- 
ligence activity globalization or globalization of intelligence (Svendsen, 2008).

Intelligence activities as a social and political phenomenon are not a new product and their origin and genesis can be seen as a consequence of certain relationships that have developed since the foundation of the first human communities. At the time, the need emerged for information of different nature and values. There were various reasons for this and the special one was to protect the most vital secrets of these communities. Otherwise, making them revealed, communities might have suffered unforeseeable damage. So, with the development of human society, civilization, science and technology, different ways of gathering information was evolving, too, which is synonymous with an aspect of the intelligence activity concept taken in its modern sense, as well as the way to protect and use their own data obtained by different method, which was later set aside as a separate building block for the general concept of intelligence activities as the counterintelligence activity.

Intelligence activity has been developing and modernizing over time trough new ways of collecting, processing and analysis, and integration of information necessary for evaluation of certain events and phenomena, as well as for strategic decisions at the national level, primarily related to national security and the realization of national interests. This can be seen and many classic works dealing with the survival and development of state and society, in which the key themes are safety, skills of conquering (waging wars) and defending, ruling wisdom and survival of the ruling elite, creating alliances and anti-unions, detecting of enemy's intentions, and so on. Let's recall the works such as: The History of the Peloponnesian War, Arthasastra, The Art of War, Macbeth, Henry V, or Il Principe, that are just dedicated to these topics. Famous Shakespeare used the term intelligence in his tragedies, recognizing its importance for security, diplomacy and warfare. Also, in Kautilya's Arthasastra it is mentioned that some spies were performing many important tasks for the wise and unprincipled ruler. These spies are not only tasked to collect information - they increase the king's authority, created the conditions for his inviolable power, and spread prophecies about him to scare his opponents (Gill, Marrin \& Phythian, 2009). In these and many other written sources, some of the key areas of interest are secrets of both opponents and allies. The reason is that the maintenance in power, military glory and conquest success, or under contemporary conditions: achieving, maintaining and improv- 
ing national security and the realization of national interests, always have been based on taking advantage of sources of threats, especially the timely detection of an enemy's secret which is, in fact, the very essence of intelligence activity. For example, Karl von Clausewitz valued intelligence information, saying that knowledge about the enemy and its country is the foundation or basis for our ideas and actions, or given the other quotation, that we should trust only reliable intelligence information, and yet we should never stop doubting. According to Clausewitz, the reason for these doubts is the fact that much intelligence information is not accurate and requires caution in their analysis and use in decision-making during the war. However, in time of war information on the strength of the opponent are uncertain, and estimates of our forces are usually unrealistic, and therefore increase the need for reliable intelligence findings. The side that has this kind of information has a chance to achieve a strategic advantage in the warfare, based on surprise. Nevertheless, being a good idea in theory, it is extremely difficult to achieve strategic surprise in practice (Ferris, 2005). This idea suggests that the intelligence activity was always an inevitable activity that governments have thoroughly sought to develop as well as they could. Besides this idea, there are many other contemporary thoughts about the need of strategic advantage achievement in war and peace by means of well-organized intelligence activities, resulting in accurate, timely and reliable intelligence information about the plans, intentions and potentials of the enemy (Bajagić, 2010).

In the social science that has a focus on intelligence activity, the key question is whether it is only useful and necessary knowledge required by political decision-makers, or it also involves espionage, covert action, etc. The aim is to determine how intelligence activity contributes to achieving dominance, understanding events and processes, political decision-making and other desired outcomes, and in this regard, how it contributes to the most important factors that could resolve this dilemma. Therefore, in recent studies of the phenomenon of intelligence activities the focus is on the following issues: 1/ what are the worthy elements of the Intelligence Theory, in general terms?; 2 / Is the intelligence activity a broad area or it can be included in one theoretical frame?; 3/ Are the theoretical foundations of the intelligence activities changing - are they subject to change? A possible answer to the dilemma whether the constitution of the intelligence activity theory should help scientists, enabling them to explain better the nature of this 
phenomenon, or those who plan and carry out intelligence activities (sources of information, analysts, managers, political decision-makers and others.), may be that " by definition, a good intelligence theory should support the very intelligence activity" (Treverton, 2006).

Intelligence activity is not merely a "theory" in relation to practice, although the fact is that it cannot live and develop without the theory. So we can talk about Intelligence Activity Studies, or the Theory of Intelligence Activities. Despite the fact that some researchers consider that the intelligence activity is an issue the least understood and mostly theoretically under-theorised area, they do not exclude the need of its development and shaping as a separate but associated, widely understood area of international relations, that is the general theory of politics. But use of the term "theory" requires determination of the priorities in studying the phenomenon of intelligence activities, based on strict scientific methodological criteria. It requires also inclusion and labelling these priorities as a certain "system of subject, meaningful statements about the general provisions ..." within the frame that constitutes intelligence activity and to which we must approach by using known ways of conceiving scientific theories such as: "Analytic deductive method, generalisation-empirical-analytical method, empiricaldeductive method, hypothetical-deductive method, and the complex/ combined method." In order to talk about the theory of intelligence activities, it must meet several important criteria: "First, it must be complex intellectual creation of abstract scientific thinking. Second, it should consist of a system of existing and presumed or possible knowledge about the science subject or a part of it, even about the method of the science. Integral components of this theory must be: scientific principles and axioms, scientific laws, scientific concepts, attitudes, judgments and conclusions, scientific theorems, scientific hypotheses and scientific reasons" (Ibid).

The general notion of theory can be defined in several ways. In the broadest sense, the theory is considered "any abstract thinking", while the narrower meaning refers to "scientific theory, or the theory of a certain science, further, the theory of scientific discipline, as well as the theory within these mentioned above which is related to the subject or a part of the subject of this science or scientific discipline" (Ibid). In the centre of our interest is primarily the concept of scientific theory, taken to mean "a system of subject, meaningful statements about the general provisions of objects or relations of science subjects and the parts of the 
science" (Ibid). Scientific theory itself has a few important definitions: $1 /$ "Theory is very complex intellectual creation of an abstract scientific thinking; 2/ Theory makes a system of existing knowledge and assumed or possible knowledge of the subject or a part of the science subject; furthermore, the knowledge of the method of science; $3 /$ Components of the theory are: scientific principles and axioms, scientific laws, scientific concepts, attitudes, judgments and conclusions, scientific theorems, scientific hypotheses and scientific reasons (Gaćinović, 2009a); 4/ Theories can be expressed linguistically or symbolically, or as a symbolic linguistic form; 5/ In political science, scientific theories for their subject have political processes and phenomena, therefore, political history, actuality and future; 6 / Scientific theories ... are never arbitrary and random, but are leaned on and stimulated by the existing scientific knowledge (Ibid).

Based on this definition of scientific theory, specified for the field of political science, the following can be said of the intelligence activity theory:

1. Although in its infancy, the Theory of Intelligence Activities is a complex intellectual creation of abstract scientific thinking, based on intelligence empirical quality or practice, which is part of the actual political practice in the broadest sense, and some of its phenomena and processes.

2. The Theory of Intelligence Activities also consists of the existing system of empirical knowledge about the effects of modern intelligence services as well as governmental specialized agencies, having their focus on political and other processes and phenomena in a certain state and its local and global environment.

3. The components of the Theory of Intelligence Activities are the scientific principles and axioms, scientific laws, scientific concepts, attitudes, judgments and conclusions, scientific theorems, scientific hypotheses and scientific reasons. First, Theory of Intelligence Activities uses for teaching well-known and accepted scientific concepts (state, nation, security, party, government, opposition, interests, etc.) statements, attitudes (the meaning of the statement which has a cognitive value), judgments and conclusions. Second, it consists of the already adopted scientific theories, and is particularly characterized by strong scientific reasons, or need of explaining scientifically the Intelligence activity seeing in all its complexity, as a specific social and political activity and the phenomenon. 
4. The Theory of Intelligence Activities is also expressed primarily by linguistic means and logical meaningful system of utterances.

5. The Theory of Intelligence Activities, as one of the scientific theories in political science, taking into account the definition of scientific theory, is and must be understood as part of the policy theory in its broadest meaning and disciplines that fall into it, because the basic objects of her interest are political processes and phenomena, as well; and that is political past, present and future, and other areas of human activity in its broadest context.

6 The Theory of Intelligence Activities, as already pointed out, is not native and spontaneous, but it is getting established and is further developing within the field of the existing knowledge, both from the broadest political science, and other social sciences and scientific disciplines that fall into them (Bajagić, 2010).

Reviewing of the scientific foundation of the term "theory of intelligence" is aimed at providing the initial framework for its further development, if we accept the fact that it is a rapidly developing theory in recent decades, as a part of the political science and at the intersection of the theory of foreign policy, international relations, science of security, and national and international security (Sims \& Gerber, 2005).

Previous studies of intelligence activities as a social and political phenomena indicate that the majority of the above requirements has been mostly fulfilled. Namely, the notion of intelligence almost always occurs along with some basic concepts of political theory, such as: war, peace, power, rule, political institutions, security (national, international and global) political interests and objectives, and others. Also, intelligence activities researches abound in the attitudes, judgments and conclusions about the importance of intelligence activities for survival, security and development of the state (for example, "Regardless of the purpose that is used for, the intelligence activity is the first line of defence ...", or "intelligence activity is one of the official channels of information in making foreign policy decisions, "etc.). Placed in the context of social science, in the first place political science and theory of international relations, intelligence activities make an unavoidable subject of scientific research and opinion. Intelligence activity has its own "history", a place in political practice that cannot be disputed since the founding of the first state communities up to the constitution of a modern state, whose structure includes network of different political institutions, through whose impact is reflected in the dynamic state functions. 
Finally, in the information revolution era and the emergence of the "soft power", intelligence activities appear as an unavoidable category that requires a precise explanation of its internal structure, thus enabling scientifically based explanations on all characteristics of the phenomenon and determination of its importance in the political processes (making foreign policy decisions, realization of national interests, protection and improvement of national security, achievement of information dominance in the broadest sense, etc.). These attitudes legitimize the use of the name "theory of intelligence activities" in the scientific sense. Also, when it comes to the theory of counter-intelligence work, the researchers believe that it is part of "broader intelligence theories" which has emerged and developed alongside the traditional realist school within the theory of international relations (Johnson, 2007). In operational terms intelligence theory must take into account the following: $1 /$ intelligence cycle is the basic model and framework of thinking about the phenomenon of intelligence activity and actions and building of the intelligence system; 2/ intelligence should not be seen primarily as a collection of intelligence information, but as the innovation of knowledge from other scientific fields because it has a lot learn from them 3/ analysis and intelligence gathering are not two different activities, but they are two different ways of getting knowledge.

Like all theories, The Theory of Intelligence Activities suffers some conceptual, content and other criticism. Some researchers believe that the theory of intelligence activities is too narrow, basing their criticism on definitions of the intelligence activities as the lever of power, which by application of the espionage in the narrow sense as well as the covert actions, provides states with an ability to behave aggressively and resort to terror (Sims \& Gerber, 2005). Although historically it was part of the content of intelligence services work, they are not only responsible for these activities. First of all, intelligence, carrying out the complex intelligence activities, is obliged to provide political decision-makers with such information that reveals intentions and plans of other states, and interpret them in the frame of foreign policy decisions making, in a way that enables the latter to take successful and timely political action. Therefore, research of the intelligence activities phenomenon is not merely aimed at description of the institutional activities of the intelligence services, but also at analysis of the causes that occur as a result of its active participation in political processes and events. This 
fact, among other things, justifies denying criticism that the Theory of Intelligence Activities is narrow (Bajagić, 2010).

On the other hand, the Theory of Intelligence Activities is criticized for being too broad, that is to say, for including areas that cannot be integrated into a coherent and distinctive system of judgements, knowledge, etc., to ensure the legitimacy of the name "theory." Studying the phenomenon of intelligence activities, many other scientific fields are really encroached by using their conceptual and categorical apparatus and the known scientific judgments and attitudes. But this does not diminish at all the exclusivity of intelligence activities in the sense that this historical, social and political phenomenon needs to be thoroughly analysed. Also, the triggers, the causes and effects of its creation and survival are to be recognized and finally, a specific forecast of future development of intelligence activities and its role and importance in the prevention of modern security threats have to be provided. To answer these questions, it is necessary to build the Theory of Intelligence Activities not without rich scientific inheritance with its tested and proven systems of scientific knowledge in the field of sociology, history, political theory, international relations, foreign policy, and other scientific disciplines, particularly of contemporary security studies. Thus the phenomenon of intelligence activities will not stop at the level of description and conceptual analysis. It will provide full legitimacy to the name of "a theory of intelligence", forming at the same time a separate conceptual and categorical apparatus, its own problems and subjects of studies (Gaćinović, 2009b), development of a specified methodological framework within the general methodological principles (Gill, Marrin \& Phythian, 2009).

Political science researchers, historians, psychologists and intelligence professionals have played an important role in creating the kind of intelligence paradigm (Wirtz, 2007). Those who take surveys within this paradigm, unlike the majority of other who have made the efforts in the social sciences, are primarily interested in the methodology, data, problems that need to be solved, as well as problems that remain for the future investigation (Gill, Marrin \& Phythian, 2009). Most researchers deal with the intelligence cycle and see it as follows: definition and transmission of intelligence requirements, collection and analysis of intelligence data, converting them into the final intelligence knowledge, and their transfer to users. The intelligence scholars' focus also should be on the analysis of intelligence failures, which can occur at any stage 
of the intelligence cycle if intelligence professionals and policy do not respond to any of the following questions: $1 /$ Who? - Including identification of the opponent, 2/ Whether? - In response to the question of the attack probability assessment, 3/ What /How? - Which refers to determining of the sort of action, 4/ Where? - That is, the position/location of the attack, 5/ When? - As an estimation of time of action, and 6/ Why? - Determining the motive behind the initiative for action (Wirtz, 2007).

This seeks to encourage understanding of the intelligence errors and to improve the practice of analyzing and transferring of the intelligence information. Looking for answers to these questions, scientists and practitioners focus on the four levels of analysis: a/ factors, specific to the production of final intelligence knowledge; $b$ / human cognition, $\mathrm{c} /$ organizational behaviour, and $\mathrm{d} /$ the relationship between the intelligence community and the police. However, the analysts mostly explore the problems that lead to difficulties in the implementation of the intelligence cycle.

The Theory of Intelligence Activities has been developing gradually along with the history of state and the law, the political theory and other social sciences (foreign policy, the theory of international relations, diplomacy, etc.), besides all conceptual and subject limitations (Quinlan, 2007). That is why we define it as interdisciplinary and multidisciplinary field, which bases its researches mainly on understanding of all aspects of policy as practice and security in the broadest sense, but primarily as relations of power and knowledge, or more precisely, as a relationship between power and intelligence of knowledge, and between different types of power and different types of knowledge (Scott \& Jackson, 2008). Knowledge is power - sometimes, according to Richard $K$. and Betts. But this knowledge does not speak for itself. It must be useful for those who are trying to reach it (Betts, 2007). Knowledge as a power, in the context of the needs and actions of the political power holders, must be integrated, accurate and useful for making strategic decisions. This knowledge is derived, among other things, from the implementation of intelligence activities.

Under the conditions of globalized reality of the international relations, there is an increase in talking about the imperative of achieving the information power in relation to entities that in any way can endanger the interests and values of a given society or the state, even the existing interstates alliances and old/new forms of intergovernmental cooperation. It is immaterial whether they are governments, unions, 
or transnational, supranational or sub-national actors (global terrorist organizations, transnational organized crime, etc.). The goal is timely detection of intentions, goals and interests of others by the means of the intelligence activity implementation, in order to properly establish a clear and comprehensive strategy for the protection of their own interests, values and goals (Scott, \& Jackson, 2004). Therefore, in contemporary conditions of international relation development, intelligence activity is considered one of the primary elements, if not the key element of national power of each state. The state is again the centre of attention, because despite the emergence of new actors and new structure of relations in a globalized world, it still remains the main subject of international relations. On the other hand, intelligence activity, which results in a final intelligence information, is an inevitable necessity in any modern state. But the intelligence activity is not only important for national policy and national security, dominant issues during the twentieth century, especially during the Cold War. Intelligence activity has never been more important to global politics than at the beginning of XXI century, which is confirmed by almost every day, primarily because of its importance in the prevention of global challenges and security threats, especially terrorism of global reach (Ibid).

The traditional elements of the national power, known from the Cold War, did not lose their importance even in the new international circumstances of the XXI century. As the established doctrine of international relations, the following elements were usually discussed: geography, as the most stable element of national power; natural resources (food supplies and raw materials); industrial capacity, military preparedness and military technology, military leadership, quality and quantity of the armed forces; the population - its number and development tendencies; the national character and the national morale, with their decisive factors such as quality of the society and government; quality of diplomacy, though unstable, it is the most important element of national power, in other words its brain; quality of the government, reflected in good balance of material and human resources of the country on the one hand, and foreign policy on the other hand, that is, the balance between different sources that are available in providing moral support for the government's foreign policy (Morgenthay, 1993). As a rule, from these elements of power, the quality of the government/ authorities has been singled out as immeasurable and certainly a key element of national power of the state, implying good balance of material 
and human sources and the foreign policy. Given what are the current elements of national power, the information power has imposed itself as one of the key elements of this power, which makes the "unity of the traditional information channels and resources used by each country in order to be informed about the status, opportunities and changes in the international/external environment. This power consists of diplomacy, other governmental information systems (media), and intelligence institutions unified into national intelligence and security system. That is why every country is trying to establish intelligence and security system through the executive functioning. The system mentioned is the subsystem of a wider national security system with its specialized agencies that conduct intelligence, counterintelligence and other security activities, in line with defined national interests and national security strategy.

Intelligence and security system as part of national security system and the executive as a whole, together with the diplomacy and the armed forces, make crucial lever for achieving, maintaining and improving national security and national interests as superior ideals of every nation or state. In theory, this informational (intelligence) power is increasingly called - "soft power" which in the era of information revolution and globalization of overall international relations, receives more and more important. One aspect of the informational/soft power is the intelligence activity, differently determined as an old/new phenomenon by the scientists and experts. Intelligence activity, which results in a final intelligence information, is considered unavoidable necessity in any state, not as a separate activity but as an integral part of it (Johnson, 2007). This is so because intelligence activity is not like any other activity of the government. It is close to political power, along with information intelligence function, and preventive security function, used for the national security, because the current, evaluative and warning intelligence provides political power holders with information superiority over its rivals and opponents both at internal and external level (Bajagić, 2010).

The close connection between the power and intelligence, or the government's ability to be timely informed about the intentions of others, is reflected in the following five functions or variables, which can be used as a measuring instrument in the analysis of any state's power: 
1. Information-gathering function (that is about how the state defines information needs and how it collects, analyzes and uses these information).

2. Function of decision making (whether the state can consolidate all their resources in an effective strategy).

3. Function of providing funds (the manner in which state can provide the elements of power to achieve strategic objectives).

4. Function of a choice of using resources (the efficacy of the state in organizing all the resources that it has).

5. Resistance function (how much the state is flexible to the demands and challenges that come from other countries).

Given these functions by which we analyze the power of the state, it can be said that the intelligence activity is an inevitable within the first function, and plays an important role in the fifth function. Knowing intentions and resources of other countries, it is much easier to them resist. Therefore, intelligence activity is an important part of state power. The power as the ability to influence other countries in a predictable way is crucial and essential to national security (Ibid).

Intelligence activity is no myth, even though is thus shown in the popular spy movies and novels. It has rich history and in reality is a regular activity, which includes timely collected and processed intelligence data, further processed and analysed to the stage of the final intelligence findings that are presented in the form of final and verified information on an issue, phenomenon or event as the underlying of the political power (Johnson, 2007). Therefore, a layman's perceptions and lack of understanding the true nature of intelligence activities and its role in political processes and international relations impose the need of providing answers to many questions (Scott \& Jackson, 2004). However, the key question for scientific research of the intelligence activity phenomenon is: "What, in fact, is meant by intelligence activities (intelligence)"? There is not any unique and common accepted definition of this concept and its internal structure, even in the scientific and professional literature on intelligence activity research and its role in achieving, maintaining and promoting of national security, the realization of national interests, and adoption and implementation of (foreign) policy decisions (McDowell \& Godman, 2009). There are many reasons for that, starting with those of social, political, ethical, ideological, and conceptual nature. Also, in determining the concept of intelligence 
activities (intelligence), various analytical and conceptual approaches and expressions have been applied in different countries. So, scientific and theoretical addressing this issue requires detailed analysis of the known definitions of this term (Bajagić, 2004). Although some authors believe that the intelligence activity is least understood and most researched area in international relations theory (Scott \& Jackson, 2004), it does not inhibit the researchers to continue searching for an acceptable definition of intelligence activities. So the intelligence activity is understood as the power, the building block of comprehensive national power of a state, or as a means of using this power, whether in the form of offensive power, or understanding one's environment and opportunities, that is, understanding the method of using force or power and against whom (Boyce \& Maiolo, 2003). Notwithstanding these views, intelligence is the indispensable category in the study of contemporary international realities, particularly in the context of the new security environment of the XXI century. Namely, in addition to its role in understanding the nature of the globalized challenges and security threats in the twenty-first century, as well as the assessment and prognosis of their further strengthening, intelligence activity has become the backbone of the operational strategies of global security operations, such as, for example, the "strategy of pre-emptive war", conceived within the administration of George W. Bush, as a result of the terrorist attacks of September 11, 2001. In the frame of this strategy, intelligence is defined as "offensive hunt strategy ", which links it directly and anew with the political power in the broadest sense (Ibid).

\section{Младен Бајагић \\ ЧЕМУ ТЕОРИЈА О ОБАВЕШТАЈНИМ АКТИВНОСТИМА}

\section{Сажетак}

У овом раду учињен је напор да се добије обиман преглед и да се анализирају различита појмовна одређењ а обавештајних активности добијених индивидуалним и теоријским истраживачким напорима као и многе институционалне дефиничије у вези са овим феноменом. Штавише, у овој студији су систематично презентовани посебни истражсивачки приступи у разумевању феномена обавештајних активности и његовог појмовног одређења. Истовремено, треба имати у виду да се важна и значајна улога истраживачког проблема у овом раду (обавештајних активности) односи на очување и унапређење начионалне безбедности, као 
дела креирања спољне политике и реализације процеса. Коначно, ова тема односи се на дефинисање наиионалних интереса. Базиран на теоријским претпоставкама и узимајући у обзир општи појам научне теорије и теорије у друштвеним наукама, овај рад сагледава феномен обавештајних активности у историјском контексту и чак покушава да прикаже и оправда изградюу и појмовни апарат који су основ саме теорије о обавештајним активностима као специффичан и посебан научни приступ разумевању концепта безбедности у друштвеном и политичком оквиру, ито је феномен безбедности у најширем смислу.

Кьучне речи: обавештавање, теорија о обавештавању, спољна политика, безбедност, национална безбедност, контраобавештајна служба, тајне акичје

\section{REFERENCES}

- $\quad$ Boyce R. and J. Maiolo (2003). The Origins of World War, Two: The Debate Continues. Basingstoke: Palgrave.

- $\quad$ Betts R. K. (2007), Enemies of Intelligence: Knowledge and Power in American National Security, New York: Columbia University.

- $\quad$ Bajagić M. (2004), Obaveštajna aktivnost i spoljna politika - studija slučaja $S A D$, Beograd: Viša škola unutrašnjih poslova.

- Bajagić M. (2009). Inostrana iskustva u razvoju teorijskog i organizacionog koncepta kontraobaveštajne aktivnosti. U: Bezbednost, God. IL, No. 1-2, str. 370-385.

- Bajagić M. (2010), Metodika obaveštajnog rada, Beograd: Kriminalističko-policijska akademija.

- Bajagić M. (2011). Obaveštajna aktivnost u sistemu političke vlasti. U Politička revija, God. (XXIII)X, Vol. 28, No. 2, str. 349-370.

- Bruneau T. C. (2008), Democracy and Effectiveness: Adapting Intelligence for the Fight against Terrorism. In: International Journal of Intelligence and Counterintelligence, Vol. 21, No. 2.

- Codevilla A. (1992), Informing Statecraft, New York: The Free Press.

- DeConde A. et al. (2002), Encyclopaedia of American Foreign Policy: studies of the principal movements and ideas, New York: Gale Group, Charles Scribner's Sons.

- Der Derian J. (1993). Anti-diplomacy, Intelligence Theory and Surveillance Practice. In: Intelligence and National Security, Vol. 8, No. 3.

- $\quad$ Ferris J. R. (2005). Intelligence and strategy (Selected Essay). New York: Routledge.

- Gaćinović R. (2009a). Hipoteze u naučnom istraživanju. In Politica Review, Vol. 20, No. 2, pp. 279-296. 
- Gaćinović R. (2009b). Izbor i definisanje problema istraživanja. In Politica Review, Vol. 27, No. 1, pp. 51-66.

- $\quad$ Gill P., Marrin S. and Phythian M. (2009). Intelligence Theory: Key questions and debates, London and New York: Routledge.

- Hoogenboom B. (2006). Grey intelligence. In: Crime Law Social Change, pp. 373-381.

- Jentelson B W. and Paterson T. G. (1997). Encyclopaedia of US Foreign Relations, Volume 2. New York: Oxford University Press.

- Johnson, L. K. (1991). America as a World Power: Foreign Policy in a Constitutional Framework, New York: McGraw-Hill, Inc.

- Johnson L. K. (1996). Secret Agencies: U. S. Intelligence in a Hostile World, New Haven and London: Yale University Press.

- Johnson L. K. (2007). Strategic Intelligence 4: Counterintelligence and Counterterrorism: Defending the Nation Against Hostile Forces. Westport, Connecticut, London: Preager Security International.

- Johnson L. K. (2007). Handbook of Intelligence Studies, New York: Routledge.

- $\quad$ Kent S. (1949). Strategic Intelligence for American World Policy. Princeton, New Jersey: Princeton University Press.

- Lathrop, C E. (2004). The literary spy: the ultimate source for quotations on espionage and intelligence. New Haven and London: Yale University Press.

- Morgenthay H. J. (1993). Politics Among Nations: The Struggle of Power and Peace, Boston, Massachusetts: McGraw-Hill Co., Inc.

- McDowell D. and Godman J. (2009), Strategic Intelligence: A Handbook for Practitioners, Managers, and Users (Revised Edition), Lanham, Toronto, Plymouth: The Scarecrow Press., Inc.

- Milosavljević S. i Radosavljević I. (2003). Osnovi metodologije političkih nauka (drugo izmenjeno i dopunjeno izdanje). Beograd: Službeni glasnik.

- Quinlan M. (2007). Just Intelligence: Prolegomena to an Ethical Theory. In: Intelligence and National Security, Vol. 22, No. 1, pp. 1-13.

- $\quad$ Quiggin T. (2007). Seeing the Invisible: National Security Intelligence in an Uncertain Age. London \& Hackensack: World Scientific Publishing Co. Pte. Ltd.

- $\quad$ Ronin R. (2009). Obaveštajni rad. Beograd: Službeni glasnik, Fakultet bezbednosti.

- $\quad$ Richelson J. T. (1999). The US Intelligence Community (4th edition). Oxford: Westwiev Press.

- Russell R. L. (2010). Strategic Intelligence and American Statecraft. Cambridge: Cambridge University Press.

- Savić A. i Bajagić M. (2003). Uloga obaveštajne aktivnosti u spoljnoj politici. U: Nauka-bezbednost-policija, Vol. VIII, No. 1, str. 17-50. 
- $\quad$ Scott L.V. and Jackson P.D. (2008). Understanding Intelligence in the Twenty-First Century: Journeys in Shadows, London: Routledge.

- $\quad$ Scott L. and Jackson P. (2004). The Study of Intelligence in Theory and Practice. In: Intelligence and National Security, Vol. 19, No. 2, pp.139169.

- Scruton R. (2007). The Palgrave Macmillan Dictionary of Political Thought (3rd edition). New York: Palgrave Macmillan.

- $\quad$ Sims J. E. and Gerber B. (2005). Transforming U.S. Intelligence. Washington: Georgetown University Press.

- $\quad$ Stojanović Đ., Đurić Ž. i Lj. Despotović (2011). Konceptualni okvir za analizu državnog kapaciteta. U Srpska politička misao, Vol. 32, God. 18, str. 11-40.

- $\quad$ Svendsen A. (2008). The globalization of intelligence since 9/11: frameworks and operational parameters. In: Cambridge Review of International Affairs, Vol. 21, No 1, pp. 129-144.

- Treverton G. F. et al (2006). Toward a Theory of Intelligence. Santa Monica: RAND Corporation, RAND National Security Research Division.

- Turner M. A. (1991). Issues in Evaluating U.S. Intelligence. In: International Journal of Intelligence and Counterintelligence, Vol. 5, No. 3, pp. 275-284.

- Waltz E. (2009). Knowledge Management in the Intelligence Enterprise. London: Artech House.

- Warner M. (2002). Wanted: a definition of Intelligence. In: Studies in Intelligence, Vol. 46 No. 2, pp. 15-22.

- Executive Order No. 12333. (1981). U.S. Intelligence Activities: The National Security Council. (Electronic version). Retrieved December 01, 2009, from www.fas.org/irp/off docs/ EO12333.htm.

\section{Резиме}

Значај обавештајне активности у савременим политичким и безбедносним прочесима указује да се ради о незаобилазном друштвеном и политичком феномену, чији је развој везан још за првобитне људске заједницее, када се јавила потреба за тајнама противника и заштити виталних интереса, посебно безбедности. Даљим развојем ичивилизације она је иновирала начине прикупљања, обраде и обједињавањь информација у ияиьу процену одређених догађаја и феномена и доношење одлука које се пре свега тичу наиионалне безбедности и националних интереса. О томе говоре и многа класична дела која се баве опстанком државе, у којима су кључне теме вештина освајања (ратоваюьа) и одбране безбедност, мудрост владања, ствараюе савеза, тајне противника, постизање моћи, итд. У условима глобализоване стварности међународних 
односа, обавештајна активност је постала незаобилазна категорија, која захтева прецизна теоријска објашњења своје структуре, да би се одредила њена улога у сложеним политичким прочесима (доношењу политичких одлука, реализацији националних интереса, заштити и унапређењу националне безбедности). Сматра се да она никада није била важнија за светску политику него што је на почетку XXI века, пре свега због юеног значаја у превениији глобалних изазова и претюи безбедности. Имајући у виду различите концепцијске, аналитичке, политичке, идеолошке, етичке и друге приступе, обавештајна активност се може дефинисати као обавештајни иуклус (јединство више повезаних фаза), и заврино обавештајно знање које се уступа крајюим корисницима/стварним субјектима политичког одлучивања; она значи способност уочавања, разумевања, спознаје и суочавања модерне државе са променама у међународном окружењу у одбрани юених националних интереса и националне безбедности.

Имајући у виду актуелни значај обавештајне активности у политичкој и безбедносној пракси, данас се може с правом тврдити да се "теорија обавештајне активности” убрзано развија, као систем предметних, смислених исказа о општим одредбама до којих се долази применом познатих начина извођења научних теорија. Научни легитимитет употребе назива "теорија обавештајне активности" се темељи на чињеници да се она развијала упоредо са историјом државе и права, политичком теоријом, спољном политиком, теоријом међународних односа, дипломатијом, итд., уз сва кониептуална и предметна ограничена, и да се тренутно убрзано развија управо у пресеку теорије спољне политике, међународних односа, науке о безбедности, националне и међународне безбедности. Теорија обавештајне активности интердисциплинарна и мултидисииплинарна област, која истраживања претежно базира на разумевану свих аспеката политике као праксе и безбедности у најширем смислу, превасходно односа моћи и знања, или моћи и обавештајног знаюь (односа између појединих врста моћи и одређене врсте знања). Знање као моћ, у контексту потреба и акција носилацуа политичке власти, мора бити интегрисано, тачно и употребливо за доношење стратешких одлука, што је и основна функиија обавештајне активности. Теорију обавештајне активности чини систем искуствених сазнања о деловању савремених 
обавештајних служби које се баве истраживањем политичких и других процеса у датој држави, и у њеном ближем и ширем окружену; юени саставни делови су научни принципи и аксиоми, научни закони, научни појмови, ставови, судови и закључии, научне теореме, научне хипотезе и научни разлози. Она користи већ прихваћене и познате научне појмове (држава, наиија, безбедност, интереси, моћ, итд.), ставове, судове и закључке; и чине је већ усвојене научне теорије, а исказује се језички (путем логичких смислених система исказа). Основни предмет неног интересована су политички прочеси и појаве (политичка прошлост, садашњост и будућност) и друге области људског деловања. Најпосле, теорија обавештајне активности није аутохтона и стихијна, већ се утемељује и даљье развија на постојећим сазнањима из области политичких и других друштвених наука.

Овај рад је примљен 20. јуна 2012. а прихваћен за штампу на састанку Редакције . септембра 2012. године. 